\title{
Genetic variability of the SUR1 promoter in relation to beta-cell function and Type II diabetes mellitus
}

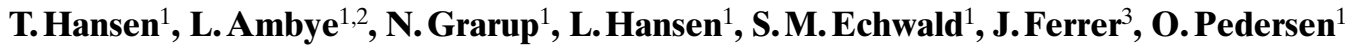 \\ ${ }^{1}$ Steno Diabetes Center, Gentofte, Denmark \\ ${ }^{2}$ Department of Clinical Biochemistry, Hvidovre Hospital, Copenhagen, Denmark \\ ${ }^{3}$ Hospital Clínic, Institut d'Investigacions Biomèdiques Agustí Pi Sunyer, Barcelona, Spain
}

\section{Abstract}

Aims/hypothesis. We aimed to examine the promoter of SUR1 for genetic variation and to determine if variants were associated with Type II (non-insulindependent) diabetes mellitus or measures of betacell function.

Methods. We examined 465 bp upstream of the ATG site in 46 Type II diabetic patients and 15 glucose tolerant control subjects by SSCP-heteroduplex analysis.

Results. We identified an a $\rightarrow \mathrm{t}$ substitution $437 \mathrm{bp}$ upstream of the ATG site. The allelic frequency was similar in 455 unrelated Type II diabetic patients and in 203 glucose tolerant control subjects matched for age $(0.036$, [95\% CI $0.019-0.053$ ] vs 0.034 [95\% CI 0.009-0.059]; $p=0.92$ ). Among the glucose tolerant subjects there were no differences between non-carriers $(n=189)$ and carriers $(n=14)$ of the variant in fasting values or $30 \mathrm{~min}$ values of plasma glucose and serum insulin during an oral glucose tolerance test. In a study of 233 glucose tolerant offspring of and spouses to Danish Caucasian Type II diabetic patients, non-carriers $(n=193)$ and carriers $(n=37)$ of the $-437 \mathrm{a} / \mathrm{t}$ polymorphism did not differ in glucose or tolbutamide stimulated insulin response during an intravenous glucose tolerance test with intravenous tolbutamide injection [AUCs-insulin (0-8) min, $2290 \pm 1660$ vs $2308 \pm 1935 \mathrm{pmol} / \mathrm{l} \cdot \mathrm{min}$ and AUCsinsulin(20-30 min $), \quad 3113 \pm 2033$ vs. $3393 \pm 2830$ $\mathrm{pmol} / \mathrm{l} \cdot \mathrm{min}$, respectively].

Conclusion/interpretation. We have identified a novel a/t polymorphism of the SUR1 gene promoter which is not associated with Type II diabetes mellitus or measures of beta-cell function. Previous reported non-functional variants of SUR1 associated with Type II diabetes mellitus still need to be accounted for. [Diabetologia (2001) 44: 1330-1334]

Keywords SUR1 gene, promoter, Type II diabetes mellitus, beta-cell function.
Type II (non-insulin-dependent) diabetes mellitus is a clinical syndrome that is likely to result from a complex interaction between environmental and genetic factors. Recently, several monogenic forms of Type

Received: 24 April 2001 and in revised form: 26 June 2001

Corresponding author: Torben Hansen, MD, PhD, Steno Diabetes Center, Niels Steensens Vej 2, DK-2820 Gentofte, e-mail: toha@ dadlnet.dk

Abbreviations: SSCP, single-strand conformation polymorphism; RG-PCR, restriction site generating-polymerase chain reaction
II diabetes have been identified [1-3]. Furthermore, genetic variation in the gene encoding calpain-10 is associated with late-onset Type II diabetes among Mexican-Americans [4] and altered glucose metabolism among Pima Indians [5]. Other genetic components of the more common form of late-onset Type II diabetes among Caucasian subjects are not known. The sulphonylurea receptor (SUR1) is a subunit of the pancreatic beta cell ATP-sensitive potassium channel $\left(\mathrm{K}_{\mathrm{ATP}}\right.$ channel) [6, 7]. This channel consists of two subunits: the sulphonylurea receptor (SUR1), which belongs to the ATP-binding cassette superfamily, and the inward rectifier $\mathrm{K}^{+}$channel member KIR6.2. Because this protein complex is a key com- 
ponent in the regulation of insulin secretion in response to glucose or tolbutamide, the SUR1 gene has been considered a plausible candidate gene for Type II diabetes.

Recent studies in Mexican-Americans and Japanese with highly polymorphic DNA markers near the SUR1 gene located at chromosome 11p15.1 did not show evidence for a linkage of the SUR1 locus with Type II diabetes [8,9]. In contrast, evidence for linkage of the plasma glucose concentration $2 \mathrm{~h}$ after oral glucose administration was shown with markers near the SUR1 locus in Mexican-American families ascertained on a Type II diabetic proband [10]. Furthermore, screening of the coding region and intronexon boundaries of the $S U R 1$ gene revealed several polymorphisms $[11,12]$. Two polymorphisms, a silent exon $18 \mathrm{Thr} 759 \mathrm{Thr}$ variant and a $\mathrm{c} \rightarrow \mathrm{t}$ intron variant in position -3 of the exon 16 splice acceptor site have been reported to be associated with Type II diabetes or a prediabetic phenotype either alone or in combination [11-17]. Also, a silent variant in exon 31 of the SUR1 gene (AGG $\rightarrow$ AGA, Arg1273Arg) is associated with hyperinsulinaemia in non-diabetic Mexican-Americans [18] or with Type II diabetes in French Caucasians [19]. In aggregate, association or linkage to diabetes or associated phenotypes have been identified in at least nine independent studies [10-19]. However, none of the sequence variants analysed have been reported to be functional and are therefore likely to be linked to mutations which alter the function or the expression of the gene. It is well known that the control of gene function is not limited to the coding regions. It is conceivable that intronic mutations alter RNA splicing creating variant exons and thus variant SUR1 protein. It is also possible that promoter variants, or even regions as far away as $100 \mathrm{~kb}$ could alter $S U R 1$ expression.

Recently, the promoter of the SUR1 gene was cloned $[20,21]$. Studies using transfection of promoter constructs in cultured cells have shown that both mouse and human SUR1 5'flanking regions are highly GC-rich, lack a TATA box, and contain sequence elements within the 5' flanking $200 \mathrm{bp}$ required for high expression in beta cells $[20,21]$. We examined the minimal promoter of the $S U R 1$ gene for sequence variants associated with Type II diabetes and for a possible influence of genetic variants on intravenous glucose and tolbutamide stimulated insulin release.

\section{Subjects and methods}

Subjects. Mutation analysis was done using single-stranded conformation polymorphism (SSCP) combined with heteroduplex analysis on genomic DNA from 15 glucose tolerant subjects and 46 unrelated Type II diabetic patients. Seven of the control subjects and 30 of the Type II diabetic patients were known heterozygous carriers of an $\mathrm{ACC} \rightarrow \mathrm{ACT}$, Thr759Thr variant and a $\mathrm{c} \rightarrow \mathrm{t}$ intron variant in position -3 of the exon 16 splice acceptor site, a genotype combination which has been shown to confer increased risk for diabetes [12]. The subsequent association studies were carried out in 455 unrelated Danish Caucasian Type II diabetic patients recruited from the outpatient clinic at Steno Diabetes Center, Copenhagen and 203 unrelated and glucose tolerant Danish Caucasian control subjects matched for age traced randomly in the Danish Central Population Register and living in the same area of Copenhagen as the Type II diabetic patients. Type II diabetes was diagnosed by 1985 World Health Organization criteria. To elucidate the impact of genetic variation on insulin secretion, phenotype-genotype studies were carried out in the 203 middleaged glucose tolerant subjects from the association study and in 60 families with a Type II diabetic proband. Only families with a Type II diabetic parent, a spouse without known diabetes and four or more offspring were asked to participate, and only data from 233 normal glucose tolerant family members were used for phenotype-genotype studies. The number of participating offspring varied from 2-11 per family. In most families 4 offspring were examined. All participants underwent a standard $75 \mathrm{~g}$ OGTT. In addition, all non-diabetic family members underwent a tolbutamide modified, frequently sampled IVGTT within 1 week after the OGTT examination. After a $12 \mathrm{~h}$ fast, venous blood samples were drawn in triplicate at $-10,-5$ and $0 \mathrm{~min}$ before the IVGTT and at 2, 3, 4, 5, 6, 7, 8, $10,12,14,16,19,22,23,24,25,27,30,35,40,50,60,70,80,90$, $100,120,140,160$ and $180 \mathrm{~min}$ for analysis of plasma glucose and serum insulin. At $\mathrm{t}=0 \mathrm{~min}$ glucose was injected intravenously into the contralateral antecubital vein for $1 \mathrm{~min}(0.3$ $\mathrm{g} / \mathrm{kg}$ body weight of $50 \%$ glucose). At $20 \mathrm{~min}$, a bolus of $3 \mathrm{mg}$ tolbutamide/kg body weight (Orinase, Upjohn, USA) was injected during $5 \mathrm{~s}$ to elicit a secondary beta-cell response. Glucose induced acute serum insulin response [AUCinsulin $(0-8 \mathrm{~min})]$ was calculated as the incremental areas under the curves from 0 to $8 \mathrm{~min}$. Tolbutamide induced serum insulin response [AUCinsulin (20-30 min)] was calculated as the incremental areas under the curves 0 to $10 \mathrm{~min}$ after tolbutamide injection. All the examined participants were Danish Caucasians by self report. Before participation informed consent was obtained from all study participants. The protocol was approved by the Ethics Committee of Copenhagen and was in accordance with the Helsinki declaration II.

Biochemical variables. The plasma concentration of glucose was analysed by an automated glucose oxidation method (Granutest: Merck, Darmstadt, Germany). For all participants the concentration of specific insulin (excluding des(31,32)- and intact proinsulin) in serum was measured by ELISA and the concentration of serum C-peptide were measured by RIA using Steno Diabetes Center routine methods.

Primary mutation analysis of the promoter region of the SUR1 gene. The minimal promoter region (GenBank accession no. AF053478, position: $-465-+107 \mathrm{bp}$ ) was examined in three segments by combined SSCP and heteroduplex scanning with two different experimental settings as described previously [22]. The segments were amplified using specific primers: segment 1 (258 bp): SUR1.prom-1f: 5'-cag gtg gtg gag cag ggc g3', SUR1.prom-1r: 5'-aaa gca gcc gtt gtt gag gac-3'; segment 2 (318 bp): SUR1.prom-2f: 5'-ccg gca aca tct ggg agc ac -3', SUR1.prom-2r: 5'-cag gaa aca gct atg acc ggt tct cgc tgc cgc aga ag-3'; segment 3 (298 bp): SUR1.prom-3f: 5'-tgt aaa acg acg gcc agt a cca cgc cca ggt gaa ctc aca-3', SUR1.prom-3r: 5'cag gaa aca get atg acc ccc gac cgg ccc tgc tac-3'. When using Amplitaq polymerase (Perkin Elmer, Calif., USA) (segment 3) PCR conditions were: denaturation at $94^{\circ} \mathrm{C}$ for $3 \mathrm{~min}$ followed by 35 cycles of denaturation at $94^{\circ} \mathrm{C}$ for $30 \mathrm{~s}$, annealing 
at $65^{\circ} \mathrm{C}$ for $30 \mathrm{~s}$ and extension at $72^{\circ} \mathrm{C}$ for $30 \mathrm{~s}$ with a final extension at $72^{\circ} \mathrm{C}$ for $9 \mathrm{~min}$. When using $\mathrm{Pfu}$-polymerase (Stratagene La Jolla, Calif., USA) (segment $1+2$ ) PCR conditions were: denaturation at $98^{\circ} \mathrm{C}$ for 3 min followed by 35 cycles of denaturation at $98^{\circ} \mathrm{C}$ for $1 \mathrm{~min}$, annealing at $65^{\circ} \mathrm{C}$ (segment 1) $/ 55^{\circ} \mathrm{C}$ (segment 2) for $1 \mathrm{~min}$ and extension at $72^{\circ} \mathrm{C}$ for $1 \mathrm{~min}$ with a final extension at $72^{\circ} \mathrm{C}$ for $9 \mathrm{~min}$. All PCR reactions were carried out using a GeneAmp 9600 thermal cycler (Perkin Elmer). PCR amplification was carried out in a volume of $25 \mu \mathrm{l}$ containing $100 \mathrm{ng}$ genomic DNA, 1 - PCR buffer (Pfu-buffer for segment 1 and 2, Taq-buffer for segment 3), $0.2 \mu \mathrm{mol} / \mathrm{l}$ of each primer, $0.2 \mathrm{mmol} / \mathrm{l} \mathrm{dNTP}$, and for segment 1 and 20.31 unit Pfu-polymerase, for segment 30.35 unit Amplitaq polymerase and $2.0 \mathrm{mmol} / 1 \mathrm{MgCl}_{2}$. The variant in segment 3 identified by the SSCP/heteroduplex scanning was examined by direct sequencing on both strands using ABI Prism Dye Primer Cycle Sequencing Kit with Amplitaq DNA polymerase and ABI prism 373 (Perkin Elmer).

Genotyping of sequence variants in the SUR1 gene promoter. The $S U R 1$ gene promoter a $\rightarrow \mathrm{t}$ variant 437 base pairs upstream of the ATG site, was detected using restriction site generating PCR (RG-PCR) amplification of the DNA segments encompassing the variant. The amplification was carried out in a volume of $25 \mu \mathrm{l}$ containing $100 \mathrm{ng}$ of genomic DNA, $2.0 \mathrm{mmol} / \mathrm{l}$ of each dNTP, $1.0 \mathrm{mmol} / \mathrm{l}$ of $\mathrm{MgCl}_{2}, 8 \%$ dimethyl sulfoxide, 5 pmol of each primer (forward primer 5'-accacgcccaggtgaactcacactccgg-3', reverse primer 5'-cagatgtttccggagtggct-3'; mismatch bases are underlined), 0.35 units of Ämpli Taq Gold DNA polymerase (Roche, Perkin Elmer), and 1 PCR Buffer II (Roche, Perkin-Elmer/Cetus, Norwalk, Conn., USA). The PCR (Perkin Elmer 9600) started with denaturation at $94^{\circ} \mathrm{C}$ for $10 \mathrm{~min}$ followed by 35 cycles of denaturation $\left(94^{\circ} \mathrm{C}, 30 \mathrm{~s}\right)$, annealing $\left(55^{\circ} \mathrm{C}, 30 \mathrm{~s}\right)$, and extension $\left(72^{\circ} \mathrm{C}, 30 \mathrm{~s}\right)$, completing with a final extension at $72^{\circ} \mathrm{C}$ for 9 min. RFLP was detected after overnight digestion with 2.5 units of BspEI (New England Biolabs, Beverly, Mass., USA) that cuts the wild type allele at a restriction site (T/CCGGA) introduced by the forward primer. The fragments (wild-type: 173,32 , and $24 \mathrm{bp}$; heterozygous: 197, 173, 32, and 24 bp; homozygous: 197 and $32 \mathrm{bp}$ ) were electrophoresed on a $4 \%$ agarose gel ( $2 \%$ GTG Nusieve, $2 \%$ Seakem Agarose) and made visible in ultraviolet illumination by staining with ethidium bromide.

Statistics. Fishers exact test was used to test for differences in allele frequencies. For genotype-phenotype studies, normal distribution of the residuals was visually verified and if necessary logarithmically transformed. SAS (ver. 6.12) or Statistical Package of Social Science (SPSS) for Windows, version 9.0 were used for analysis. Analysis of data from middle-aged normal glucose tolerant subjects was done using a generalized linear model, with sex and genotype as fixed factors and BMI and age as covariate factors. Family data were analysed using a variance component model (random effects model), where an extra source of variation is allowed to account for the fact that subjects from the same family might be correlated. The variant of interest and sex were included as fixed variables, BMI and age as covariate factors, and family as a random factor. A $p$ value of less than 0.05 was considered statistically significant.

\section{Results}

The SUR1 gene promoter has been examined $465 \mathrm{bp}$ upstream of the ATG site in 61 subjects by SSCP-heteroduplex analysis. We identified an a to $t$ substitu-
Table 1. Clinical and biochemical data of middle-aged Danish Caucasians when classified in accordance to their genotype of the $-437 \mathrm{a} \rightarrow$ t nucleotide polymorphism of the SUR1 gene promoter

\begin{tabular}{llll}
\hline & $\mathrm{a} / \mathrm{a}$ & $\mathrm{a} / \mathrm{t}$ & $p$ \\
\hline$n$ & 189 & 14 & \\
Sex (men/women) & $96 / 93$ & $10 / 4$ & \\
Age (years) & $52.2(13.5)$ & $53.7(18.4)$ & 0.77 \\
BMI (kg/m $)$ & $25.2(3.8)$ & $26.3(3.2)$ & 0.21 \\
Fasting & & & \\
p-glucose (mmol/l) & $5.1(0.5)$ & $5.1(0.4)$ & $0.73(0.56)$ \\
s-insulin (pmol/l) & $42(23)$ & $40(13)$ & $0.75(0.19)$ \\
s-C-peptide (pmol/l) & $564(157)$ & $571(146)$ & $0.75(0.91)$ \\
At 30 min during OGTT & & & \\
p-glucose (mmol/l) & $7.8(1.4)$ & $7.5(1.5)$ & $0.48(0.21)$ \\
s-insulin (pmol/l) & $261(148)$ & $259(116)$ & $0.80(0.44)$ \\
s-C-peptide (pmol/l) & $1628(502)$ & $1674(484)$ & $0.66(0.96)$ \\
\hline Values are means (SD); & &
\end{tabular}

Values are means (SD); s, serum; $p$, plasma. $p$-values in parenthesis refer to results of analyses using a generalised linear model including sex and genotype status as fixed factors and $\mathrm{BMI}$ and age as covariate factors

tion 437 bp upstream of the ATG site. Only two subjects who were known heterozygous carriers of both an ACC $\rightarrow$ ACT, Thr759Thr variant and a $\mathrm{c} \rightarrow \mathrm{t}$ intron variant in position -3 of the exon 16 splice acceptor site, carried the $-437 \mathrm{a} \rightarrow \mathrm{t}$ polymorphism. The allelic frequency was similar in 455 unrelated Type II diabetic patients (a/a: $n=422 ; \mathrm{a} / \mathrm{t}: n=33 ; \mathrm{t} / \mathrm{t}: n=0)$ and in 203 glucose tolerant control subjects matched for age (a/a: $n=189 ; \mathrm{a} / \mathrm{t}: n=14 ; \mathrm{t} / \mathrm{t}: n=0)(0.036,[95 \%$ CI $0.019-0.053$ ] vs 0.034 [95\% CI $0.009-0.059$, $p=0.92)$. Among the normal glucose tolerant subjects there were no differences between non-carriers and carriers of the variant in fasting and $30 \mathrm{~min}$ postglucose load values of plasma glucose, serum insulin and serum C-peptide (Table 1 ). In a study of 233 glucose tolerant family members of Danish Caucasian Type II diabetic patients, non-carriers $(n=193)$ and carriers $(n=37)$ of the $-437 \mathrm{a} \rightarrow$ t polymorphism did not differ in fasting and 30 min postglucose load values of plasma glucose, serum insulin and serum Cpeptide or in glucose or tolbutamide stimulated insulin response during an intravenous glucose tolerance test with an intravenous tolbutamide injection [AUCs-insulin(0-8 min), $2290 \pm 1660$ vs $2308 \pm 1935$ $\mathrm{pmol} / \mathrm{l} \mathrm{min}$ and AUCs-insulin(20-30 min), $3113 \pm$ 2033 vs $3393 \pm 2830 \mathrm{pmol} / \mathrm{l} \cdot \mathrm{min}$, respectively] (Table 2). No difference in blood pressure or serum lipids was observed between carriers and non-carriers of the variant (data not shown).

\section{Discussion}

Several studies have shown associations between various non-functional variants in the SUR1 gene and Type II diabetes or a prediabetic phenotype [11-19]. 
Table 2. Clinical and biochemical data of glucose tolerant offspring and spouses of Danish Caucasian Type II diabetic patients classified according to their genotype of the $-437 \mathrm{a} \rightarrow$ t nucleotide polymorphism of the SUR1 gene promoter

\begin{tabular}{|c|c|c|c|c|}
\hline & $\mathrm{a} / \mathrm{a}$ & $\mathrm{a} / \mathrm{t}$ & $\mathrm{t} / \mathrm{t}$ & $p$ \\
\hline$n$ & 193 & 37 & 3 & \\
\hline Sex (men/women) & $89 / 104$ & $16 / 21$ & $3 / 0$ & \\
\hline Age (years) & $42.1(12.0)$ & $44.9(11.9)$ & $46.4(23.4)$ & \\
\hline $\begin{array}{l}\text { Fasting } \\
\text { p-glucose }(\mathrm{mmol} / \mathrm{l}) \\
\text { s-insulin }(\mathrm{pmol} / \mathrm{l}) \\
\mathrm{s}-\mathrm{C} \text {-peptide }(\mathrm{pmol} / \mathrm{l})\end{array}$ & $\begin{array}{c}5.1(0.5) \\
40(26) \\
489(179)\end{array}$ & $\begin{array}{c}5.4(0.6) \\
43(26) \\
549(191)\end{array}$ & $\begin{array}{r}5.3(0.2) \\
50(18) \\
665(55)\end{array}$ & $\begin{array}{l}0.12 \\
0.59 \\
0.29\end{array}$ \\
\hline $\begin{array}{l}\text { Acute responses }(0-8 \mathrm{~min}) \text { during IVGTT } \\
\text { Acute p-glucose response }(\mathrm{min} \cdot \mathrm{mmol} / \mathrm{l}) \\
\text { Acute s-insulin response }(\mathrm{min} \cdot \mathrm{pmol} / \mathrm{l}) \\
\text { Acute } \mathrm{s}-\mathrm{C} \text {-peptide response }(\mathrm{min} \cdot \mathrm{pmol} / \mathrm{l})\end{array}$ & $\begin{array}{l}62.8(9.8) \\
2290(1660) \\
6945(4172)\end{array}$ & $\begin{array}{c}64.5(10.4) \\
2308(1935) \\
5887(3372)\end{array}$ & $\begin{array}{l}63.6(9.0) \\
3595(4477) \\
7516(5434)\end{array}$ & $\begin{array}{l}0.90 \\
0.69 \\
0.41\end{array}$ \\
\hline
\end{tabular}

Values are means (SD); $s$ serum, $p$ plasma. $p$ values refer to results after variance component analyses including sex and genotype status as fixed factors, BMI and age as covariate factors and family as a random factor

Linkage disequilibrium with a functional mutation in the coding regions, exon-intron boundaries, or the promoter of the SUR1 gene is a possible explanation for these findings. The entire coding region and the intron-exon boundaries of the SURI gene have been screened for mutations in Danish and Japanese subjects $[12,23]$. Furthermore, the coding region of the Kir6. 2 gene, located $4.5 \mathrm{~kb}$ downstream of the SUR1 gene has been examined for mutations [22, 24-26]. Also, the promoter sequencies of both genes except for the minimal promoter of the SUR1 gene have been examined [27]. No variants, however, have been identified which could explain the observed associations of $S U R 1$ polymorphisms to Type II diabetes. Various degrees of linkage disequilibrium with one or more functional mutations in a nearby locus or in unexamined regulatory regions of the SUR1/ Kir6.2 genes are therefore the most likely explanation for the published associations between non-functional variants in the SUR1 gene and Type II diabetes.

In this study, the possibility that variation in the minimal promoter of the SUR1 gene might contribute to Type II diabetes susceptibility was evaluated. This region is required for high expressions in beta cells $[20,21]$ but have not been examined in previous studies due to its high $\mathrm{G}+\mathrm{C}$ content [27]. To increase the likelihood of identifying a functional variant in linkage disequilibrium with previous identified $S U R 1$ polymorphisms, we screened the promoter in 37 subjects who carried a combination of $S U R 1$ variants, an $\mathrm{ACC} \rightarrow \mathrm{ACT}$, Thr759Thr variant and a $\mathrm{c} \rightarrow \mathrm{t}$ intron variant in position -3 of the exon 16 splice ac- ceptor site, which have been shown to confer increased risk of diabetes among Danish subjects [12]. Furthermore we screened 24 randomly selected subjects for $S U R 1$ promoter mutations. We identified one promoter variant $437 \mathrm{bp}$ upstream of the ATG site. This variant was only identified in two subjects carrying the combination of SUR1 variants conferring increased risk of diabetes. It was not associated with Type II diabetes among Danish Caucasian subjects nor was it associated with altered insulin secretion during an OGTT or a tolbutamide modified IVGTT. Thus, the previous published data on the association of three different polymorphisms with Type II diabetes in various populations does not seem to be explained by the variation in the minimal promoter of the SUR1 gene. However, as the sample sizes in this study are limited to about 200 glucose tolerant control subjects, 250 glucose tolerant offspring of Type II diabetic parents and 450 Type II diabetic subjects a minor effect of the variant cannot be excluded. Also, variation in the $S U R 1$ minimal promoter could be of importance in the development of diabetes in other ethnic groups. Further studies, including examinations of haplotypes in the region seem necessary in order to identify the single variant or haplotype responsible for diabetes risk. In these analyses the possibility of compound heterozygosity for two different at-risk haplotypes conferring the increased risk for diabetes as recently described for the calpain 10-locus [4] should be considered.

Acknowledgements. The family study was supported by grants from the Danish Medical Research Council, EEC grants 
BMH4-CT98-3084 and QLRT-1999-00546, the Velux Foundation and the Danish Diabetes Association. The authors thank A. Forman, L. Aabo, H. Fjordvang, B. Mottlau, S. Urioste, S. Kjellberg, J. Brønnum and Q. Truong for their dedicated and careful technical assistance and G. Lademann for secretarial support.

\section{References}

1. Doria A, Plengvidhya N (2000) Recent advances in the genetics of maturity-onset diabetes of the young and other forms of autosomal dominant diabetes. Curr Opin Endocrinol Diab 7: 203-210

2. Accili D, Cama A, Barbetti F, Kadowaki H, Kadowaki T, Taylor SI (1992) Insulin resistance due to mutations of the insulin-receptor gene - an overview. J Endocrinol Invest 15: 857-864

3. Ouweland JMW, Lemkes HHPJ, Ruitenbeek W et al. (1992) Mutation in mitochondrial tRNA ${ }^{\text {Leu(UUR) }}$ gene in a large pedigree with maternally transmitted type II diabetes mellitus and deafness. Nat Genet 1: 368-371

4. Horikawa Y, Oda N, Cox NJ et al. (2000) Genetic variation in the gene encoding calpain-10 is associated with type 2 diabetes mellitus. Nat Genet 26: 163-175

5. Baier LJ, Permana PA, Yang X et al. (2000) A calpain-10 gene polymorphism is associated with reduced muscle mRNA levels and insulin resistance. J Clin Invest 106: R69-R73

6. Aguilar-Bryan L, Clement JP, Gonzales G, Kunjilwar K, Bryan J (1998) Toward understanding the assembly and structure of KATP channels. Physiological Reviews. 78: 227-245

7. Miki T, Nagashima K, Seino S (1999) The structure and function of the ATP-sensitive $\mathrm{K}^{+}$channel in insulin-secreting pancreatic $\beta$-cells. J Mol Endocrinol 22: 113-123

8. Stirling B, Cox NJ, Bell GI, Hanis CL, Spielman RS, Concannon P (1995) Linkage studies in NIDDM patients with markers near the sulphonylurea receptor gene. Diabetologia 38: 1479-1481

9. Iwasaki N, Kawamura M, Yamagata K et al. (1996) Identification of microsatellite markers near the human genes encoding the beta-cell ATP-sensitive $\mathrm{K}+$ channel and linkage studies with NIDDM in Japanese. Diabetes 45: 267-269

10. Stern MP, Ravindranath D, Braxton DM et al. (1996) Evidence for linkage of regions on chromosomes 6 and 11 to plasma glucose concentrations in Mexican Americans. Genome Res 6: 724-734

11. Inoue H, Ferrer J, Wellin CM et al. (1996) Sequence variants in the sulfonylurea receptor (SUR) gene are associated with NIDDM in Caucasians. Diabetes 45: 825-831

12. Hansen T, Echwald SM, Hansen L et al. Decreased tolbutamide-stimulated insulin secretion in healthy subjects with sequence variants in the high-affinity sulfonylurea receptor gene. Diabetes 47: 598-605

13. Hani EH, Clément K, Velho G et al. (1997) Genetic studies of the sulfonylurea receptor gene locus in NIDDM and in morbid obesity among French Caucasians. Diabetes 46: 688-694

14. 'tHart LM, de Knijff P, Dekker JM et al. (1999) Variants in the sulphonylurea receptor gene: association of the exon
16-3 t variant with Type II diabetes mellitus in Dutch Caucasians. Diabetologia 42: 617-620

15. 'tHart LM, Dekker JM, van Haeften TW et al. (2000) Reduced second phase insulin secretion in carriers of a sulphonylurea receptor gene variant associating with Type II diabetes mellitus. Diabetologia 43: 515-519

16. Rissanen J, Markkanen A, Karkkainen P et al. (2000) Sulfonylurea receptor 1 gene variants are associated with gestational diabetes and type 2 diabetes but not with altered secretion of insulin. Diabetes Care 23: 70-73

17. Weisnagel SJ, Rankinen T, Nadeau A, Rao DC, Chagnon YC, Pérusse L et al. (2001) Decreased fasting and oral glucose stimulated C-peptide in nondiabetic subjects with sequence variants in the sulfonylurea receptor 1 gene. Diabetes 50: 697-702

18. Goksel DL, Fischbach K, Duggirala R et al. (1998) Variant in sulfonylurea receptor- 1 gene is associated with high insulin concentrations in non-diabetic Mexican Americans: SUR-1 gene variant and hyperinsulinemia. Hum Genet 103: $280-285$

19. Reis AF, Ye W, Dubois-Laforgue, Bellanné-Chantelot C, Timsit J, Velho G (2000) Association of a variant in exon 31 of the sulfonylurea receptor 1 (SUR1) gene with type 2 diabetes mellitus in French Caucasians. Hum Genet 107: 138-144

20. Ashfield R, Ashcroft JH (1998) Cloning of the promoters for the $\beta$-cell ATP-sensitive K-channel subunits Kir6.2 and SUR1. Diabetes 47: 1274-1280

21. Hernandez-Sanchez C, Ito Y, Ferrer J, Reitman M, LeRoith D (1999) Characterization of the mouse sulfonylurea receptor 1 promoter and its regulation. J Biol Chem 274: 18261-18270

22. Hansen L, Echwald SM, Hansen T, Urhammer SA, Clausen JO, Pedersen O (1997) Amino acid polymorphisms in the ATP-regulatable inward rectifier Kir6.2 and their relationships to glucose- and tolbutamide-induced insulin secretion, the insulin sensitivity index, and NIDDM. Diabetes 46: 508-512

23. Ohta Y, Tanizawa Y, Inoue $H$ et al. (1998) Identification and functional analysis of sulfonylurea receptor 1 variants in Japanese patients with NIDDM. Diabetes 47: 476-481

24. Sakura H, Wat N, Horton V, Millns H, Turner RC, Ashcroft FM (1996) Sequence variations in the human Kir6.2 gene, a subunit of the beta-cell ATP-sensitive K-channel: no association with NIDDM in white Caucasian subjects or evidence of abnormal function when expressed in vitro. Diabetologia 39: 1233-1236

25. Inoue H, Ferrer J, Warren-Perry M et al. (1997) Sequence variants in the pancreatic islet $\beta$-cell inwardly rectifying $\mathrm{K}^{+}$channel Kir6.2 (Bir) gene. Diabetes 46: 502-507

26. Hani EH, Boutin P, Durand E et al. (1998) Missense mutations in the pancreatic islet beta cell inwardly rectifying $\mathrm{K}^{+}$ channel gene (Kir6.2/BIR): a meta-analysis suggests a role in the polygenic basis of Type II diabetes mellitus in Caucasians. Diabetologia 41: 1511-1515

27. Gloyn AL, Hashim Y, Ashcroft SJH, Ashfield R, Wiltshire S, Turner RC (2001) Association studies of variants in promoter and coding regions of beta-cell ATP-sensitive Kchannel genes SUR1 and Kir6.2 with type 2 diabetes mellitus (UKPDS 53). Diabet Med 18: 206-212 